\title{
HOUSING MARKETS IN CENTRAL AND EASTERN EUROPE: IS THERE A BUBBLE IN THE CZECH REPUBLIC?
}

\section{Petr Zemčík}
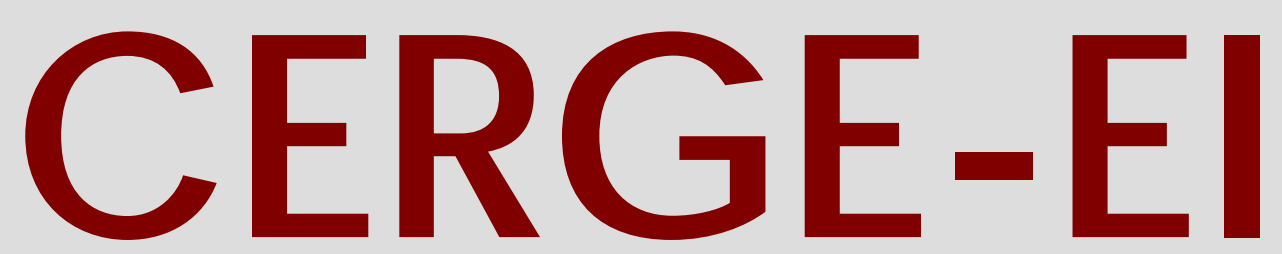

Charles University Centerfor Ec onomic Research and Graduate Education Academy of Sciences of the Czech Republic Ec onomic s Institute 


\title{
Working Paper Series 390 (ISSN 1211-3298)
}

\section{Housing Markets in Central and Eastern Europe: Is There a Bubble in the Czech Republic?}

\author{
Petr Zemčík
}

CERGE-EI

Prague, September 2009 
ISBN 978-80-7343-191-4 (Univerzita Karlova. Centrum pro ekonomický výzkum a doktorské studium)

ISBN 978-80-7344-180-7 (Národohospodářský ústav AV ČR, v.v.i.) 


\title{
Housing Markets in Central and Eastern Europe: Is There a Bubble in the Czech Republic?
}

\author{
Petr Zemčík
}

CERGE-EI, Prague*

September 2009

\begin{abstract}
Real estate prices more than doubled in many countries of Central and Eastern Europe from 2003 to 2008. In this paper, I provide the first assessment of whether housing prices in this region correspond to rents, i.e. to cash-flows related to an apartment purchase. State-of-theart panel data stationarity and Granger causality techniques are employed to test the implications of the standard present-value model using regional data from the Czech Republic. Apartment prices both in this country overall and in its capital are only slightly overvalued. In addition, changes in prices are helpful in predicting changes in rents and vice versa.
\end{abstract}

\begin{abstract}
Abstrakt
Ceny nemovitostí se v letech 2003-2008 více než zdvojnásobily v mnoha zemích střední a východní Evropy. V tomto článku nabízím první analýzu, zda v daném regionu odpovídají ceny realit výši nájmu, což je finanční tok spojený s koupí nemovitosti. Za účelem testování implikací standardního modelu současné hodnoty pro ČR jsou využity moderní testy stacionarity v panelových datech spolu s testy Grangerovy kauzality. Ukazuje se, že ceny bytů jsou jak v celé ČR, tak v Praze pouze mírně nadhodnoceny. Změn ceny bytů je možno využít $\mathrm{k}$ predikci změn nájmů a naopak.
\end{abstract}

KEY WORDS: Central and Eastern Europe, Czech Republic, panel data, unit root, bubble, house prices, rents.

JEL CLASSIFICATION: G12, R21, R31, C33.

I would like to thank Štěpán Jurajda for his comments on earlier drafts of this paper. The research leading to these results has received funding from the European Community's Seventh Framework Programme (FP7/2007-2013) under Socio-economic Sciences and Humanities, grant agreement $n$ 217466 and from the Grant Agency of the Czech Republic project 402/09/1755.

* CERGE-EI is a joint workplace of the Center for Economic Research and Graduate Education, Charles University, and the Economics Institute of the Academy of Sciences of the Czech Republic.

Correspondence address: CERGE-EI, PO Box 882, Politických vězn̆ů 7, 11121 Prague 1, Czech Republic. Email: petr.zemcik@cerge-ei.cz 


\section{Introduction}

Increasing and then rapidly decreasing property prices around the world are often cited as the initial trigger of the on-going global recession. This raises the question of whether current real estate prices correspond to economic fundamentals and if not, how much (more) they are likely to fall. This question is highly relevant for the housing markets in Central and Eastern Europe (CEE), which have experienced a recent boom of the credit markets (see Egert and Mihajlek 2007). Property prices more than doubled between 2003 and 2008 in majority of countries in this region - see Table 1. To the best of my knowledge, the present study is the first to employ panel data stationarity techniques to assess the possibility of a real estate bubble in CEE using regional data. The Czech Republic serves as a useful benchmark because its housing market is not very sensitive to the exchange rate fluctuations. The reason for this is a zero volume of mortgages denominated in foreign currency as compared with $80 \%$ in Estonia and $40 \%$ in Hungary. ${ }^{1}$ In addition, the Czech Republic is fairly representative of a country in CEE with population of 10.4 mil., GDP growth of $3 \%$ in 2008, ${ }^{2}$ and having entered the European Union in 2004.

A real estate bubble is usually defined as a discrepancy between property prices and fundamentals. This study focuses on rent as the fundamental factor, mainly due to data availability. The rent is a measure of cash-flow variable associated with a purchase of real estate, and its use naturally leads to the present-value model often employed in finance. Campbell and Shiller (1987) demonstrate that the model imposes restrictions for stationarity between financial assets and their cash flows. Specifically, asset prices and the corresponding cash-flows should be of the same order of integration. If the order of integration is one for both variables (i.e. their levels are non-stationary but the first differences are stationary), they should be cointegrated. Wang (2000) employs this methodology to conclude there was no bubble in the U.K. housing market using aggregate

\footnotetext{
${ }^{1}$ See Table 2 in Egert and Mihajlek (2007), the data are from 2006.

${ }^{2}$ Czech Statistical Office is the source of this information.
} 
data up to 1997. Mikhed and Zemčík (2009a) study the implications of the present value model in the United States. However, they use regional data and panel data stationarity techniques, which have greater power than their univariate counterparts. One of the first panel data unit root test is described in Im, Pesaran, and Shin (2003). It is based on simply averaging single-series t-statistics from standard unit root regressions. Pesaran (2007) suggests an updated version of this test robust to cross-sectional correlation, which can be tested for by a test from Pesaran (2004). In this paper, I assess stationarity of the relationship between apartment prices and rents in the Czech Republic using the above-mentioned panel data unit root tests.

There are two available types of panel data for apartment prices and rents in the Czech Republic. They differ by geographical coverage, data frequency, and the time span. The first panel consists of annual data for major cities and towns of the Czech Republic from 2001 to 2008. The second panel consists of monthly data for all the major districts of Prague, the Czech capital. It starts in July 2007 and ends in February 2009. The two datasets make it possible to compare real estate markets in the capital and in the rest of the Czech Republic. This is useful since prices in capitals are often higher than in the rest of a given country and may follow idiosyncratic trends. I run cross-sectionally robust individual unit root tests for all the regions and districts. If an apartment price has a unit root and the rent or the price-to-rent ratio are non-stationary, there is a bubble in the given region or district. Using this definition, $77 \%$ of the Czech regions and $52 \%$ of the Prague districts exhibit bubble-like behavior. However, the null hypothesis of price series being non-stationary in some locations may be accepted only because of the small power of the univariate unit root tests. To rule out this possibility and to summarize the development of the housing markets overall, I conduct the joint panel data stationarity tests. These tests combine information from all of the individual unit root regressions. The results suggest that the overvaluation of apartments is fairly small. The bubble definition is not satisfied in Prague where the price is stationary even though the price-to- 
rent ratio is not. This reflects the shorter time span of the data, which already includes a recent price decline. For the Czech Republic panel, both housing prices and rent series are not stationary. The null hypothesis of a unit root in the price-to-rent ratio is barely rejected at standard levels of significance. Therefore, technically there is a bubble but the degree of overpricing is fairly small as compared to the United States housing market in the early 2000s. Hence, a collapse of the real estate prices similar to the one in United States, Britain, Spain, Ireland, and other countries is not likely.

Finally, the question of mutual predictability of house prices and rents is addressed. The present-value value model loosely implies that house prices should be useful in predicting rents and vice versa. One can test for Granger causality in both directions. I use recently developed panel data Granger causality tests - see Hurlin (2004) and Hurlin and Venet (2004). The test can only be implemented for the data from Prague because the time span of the data for the whole Czech Republic is too short. Changes in prices do in fact predict changes in rents in Prague. Similarly, changes in rents help in predicting changes in property prices. Testing for causality in the other panel is more complex due to the low time series dimension and a different sort of panel data estimation techniques needs to be employed. Specifically, I use the Generalized Method of Moments (GMM) Arellano-Bond (1991) estimator to show that lagged differences in rents predict differences in prices while controlling for differences in lagged prices and vice versa. This result is quantitatively and qualitatively similar to the results obtained for the US data in Mikhed and Zemčík (2009a). In other words, the Czech real estate market behaves in a manner resembling the developed markets in Western Europe, the Anglo-saxon world, and in Asia.

The rest of the paper is organized as follows. Section 2 discusses the implications of the present-value model for prices and rents, and Section 3 provides an overview of the relevant panel data econometrics. Section 4 describes in detail the used data and their sources, and Section 5 presents the results. Section 6 concludes the paper. 


\section{Present Value Model for the Real Estate Market}

Here I follow closely Campbell and Shiller (1987). They express a present value model for variables $P_{i, t}$ and $R_{i, t}$ as:

$$
P_{i, t}=\theta(1-\beta) \sum_{j=0}^{\infty} \beta^{j} E_{t} R_{i, t+j}+b_{i, t}+c, \quad i=1, \ldots, N
$$

where $P_{i, t}$ is a local house price index and $E_{t}$ is a mathematical expectation conditional on information at time $t . R_{i, t}$ is a rent i.e. a cash-flow from owning an apartment between the beginning of period $t$ and the beginning of period $t+1$, and $\beta$ is the discount factor. The discount factor can be written as $1 /(1+D)$, where $D$ is the constant discount rate. ${ }^{3} \theta$ is the coefficient of proportionality and $c$ is the constant. $b_{i, t}$ is a random variable representing a rational bubble and satisfying $b_{i, t}=\beta E_{t} b_{i, t+1} \cdot{ }^{4}$ Note that changing the timing convention for the rent between the beginning of period $t$ and the beginning of period $t+1$ to $R_{i, t+1}$, setting $c=0, \theta=\frac{1}{D}$, and $b_{i, t}=0$ yields the perhaps more familiar formula $P_{i, t}=\sum_{j=1}^{\infty} \beta^{j} E_{t} \frac{R_{i, t+j}}{(1+D)^{j}}$, which is often referred to as the price representing fundamentals. The formula (1) holds for any asset in general, including stocks, bonds, etc. Here it captures the notion of a real estate purchase as an investment vehicle in a given location. Purchasing an apartment entitles the owner to a stream of future cash flows, namely the rents. This holds whether the owner lives in the apartment or not since by living there she saves on the rent she would otherwise pay elsewhere.

The present-value formula is not only very intuitive, it also is a solution to an optimization problem. In this problem, a consumer maximizes her expected life-time welfare subject to a budget constraint. Assuming a consumer is risk neutral and the discount rate is constant yields equation (1). Real estate prices and rents consistent with the present value formula are therefore consistent with consumers being rational. If $b_{t} \neq 0$, there are

\footnotetext{
${ }^{3}$ The assumption of constant discount rate is fairly strong, but in the case of the Czech Republic it is not unrealistic. The Czech National Bank reports monthly data on interest rates for fixed rate mortgages for the period from 5 to 10 years from January 2004. The minimum reported rate is $4.61 \%$ and the maximum rate is $5.63 \%$ with the majority of the rates being close to $5 \%$.

${ }^{4}$ See for example Hamilton (1986) for a more detailed discussion of speculative bubbles.
} 
solutions to the stochastic difference equation (1), which contain housing prices growing much faster than rents. This indicates the presence of a bubble. If the random variable $b_{t}$ satisfies the condition that $b_{t}=\beta E_{t} b_{t+1}$, then the bubble is rational since (1) is implied by first order conditions of the consumer optimization problem. In other words, if consumers expect real estate prices to be increasing for some time, it is in fact rational to pay a price higher than the one corresponding to the future streams of rents. These represent the fundamentals in this case.

In the absence of the bubble $\left(b_{t}=0\right)$, equation (1) relates real estate prices and rents. The equation is typically tested using some transformation of the variables present, which results in stationary series. However, there is a possibility that the series are not stationary and yet there is no bubble. The question of whether the series are stationary is empirical in its nature. Therefore, the next step is to test for unit roots in series for apartment prices and rents, with the following potential outcomes:

Case 1: $P_{i, t}$ stationary and $R_{i, t}$ stationary;

Case 2: $P_{i, t}$ stationary and $R_{i, t}$ non-stationary;

Case 3: $P_{i, t}$ non-stationary and $R_{i, t}$ stationary; and

Case 4: $P_{i, t}$ non-stationary and $R_{i, t}$ non-stationary.

I focus only on Cases 3 and 4, which indicate run-away prices. Case 3 clearly violates the implications of the no-bubble condition. Case 4 is the most interesting one since nonstationary real estate prices do not necessarily indicate the presence of a bubble. To see if the bubble is in fact present, one needs to test for the cointegration between real-estate prices and cash-flows or test for the stationarity of $P / R$.

To illustrate why testing for cointegration between rents and prices is equivalent to both testing the present-value equilibrium model and to unit root testing of $P / R$, let us define a spread variable as the difference between an apartment price and a multiple of 
rents, i.e. $S_{i, t} \equiv P_{i, t}-\theta R_{i, t}$. Equation (1) implies that

$$
S_{t}=\theta \sum_{j=1}^{\infty} \beta^{j} E_{t} \Delta R_{i, t+j}+c
$$

and

$$
S_{t}=\left(\frac{\beta}{1-\beta}\right) E_{t} \Delta P_{i, t+1}+c .
$$

Note the two formulae relate the differences in rents to differences in prices. Also, the expected capitalization of a real estate purchase can be expressed in terms of the rentto-price ratio. Setting $c=0, \theta=\frac{1}{D}$, and $b_{i, t}=0$, and re-arranging equation (3) results in:

$$
E_{t} \frac{\Delta P_{i, t+1}}{P_{i, t}}=D-\frac{R_{i, t}}{P_{i, t}}
$$

Equation (4) can be viewed as a no arbitrage condition where the expected return on investment in an apartment equals the corresponding discount rate. The price-to-rent ratio serves as a predictor of capitalization. Equation (4) hence provides a theoretical prediction for the statistical relationship (but not for a direction of causality) between changes in rents and the rent-to-price ratio. This relationship has been tested for the US data for instance by Clark (1995) and Capozza and Seguin (1996).

Non-stationarity $\Delta R_{i, t}$ translates via (2) into non-stationarity of $S_{i, t}$, which in turn implies non-stationarity of $\Delta P_{i, t}$ via (3). For the stationary spread, it follows from (2) that $\Delta R_{i, t}$ is stationary and from (3) that $\Delta P_{i, t}$ is stationary, respectively. Hence if both prices and rents have unit root in levels and the spread is stationary, the present value model implies that first differences of both variables must be stationary as well. This satisfies the standard definition of cointegration, which requires that cointegrated series should be integrated of order 1, i.e. I(1) (see for example Hamilton 1994, Ch. 19.1). Therefore, testing for stationarity of the spread is equivalent: (i) to testing for cointegration between our two variables because the spread is in fact their linear combination, and (ii) to testing of the present-value model with no bubbles. Finally, if $S_{t}=0$ then $\frac{P_{i, t}}{R_{i, t}}=\theta$ i.e. a constant. Clearly, the stationary spread means that the price-to-rent ratio is also stationary. 


\section{Econometric Methodology}

Real estate prices and rents tend to be correlated across regions. A general diagnostic test for cross section dependence in panels from Pesaran (2004) is used to find if this is in fact the case for the Czech Republic and in its capital. Testing for unit roots is then conducted using tests from Im, Pesaran, and Shin (2003) and from Pesaran (2007). Only the latter is robust to cross-sectional dependence. The former test is included because the robust test cannot be used in some cases due to the short time series span. The tests are executed both for individual series and jointly. They are applied to prices, rents, and price-to-rent ratios. ${ }^{5}$ The tests are employed to find if there is a real estate bubble in Prague and in the Czech Republic. ${ }^{6}$ In addition, the present value model (1) implies that prices should predict rents and vice versa. For Prague, this issue is addressed by the panel data Granger causality test from Hurlin (2004) and Hurlin and Venet (2004). The time period for the annual Czech data is too short to conduct such tests, and therefore the GMM Arellano and Bond (1991) estimator provides substitution.

Pesaran (2004) diagnostic test for cross section dependence in panels uses residuals from the standard augmented Dickey Fuller (ADF) regression (e.g. Hamilton 1994, Ch. 17):

$$
\Delta y_{i t}=\mu_{i}+\omega_{i} t+\alpha_{i} y_{i, t-1}+\sum_{j=1}^{p_{i}} \lambda_{i j} \Delta y_{i, t-j}+\varepsilon_{i t},
$$

with $\varepsilon_{i t}$ being an error term. $\mu_{i}$ is an individual fixed effect, $\omega_{i}$ is an individual trend coefficient and $\alpha_{i}-1$ is an autoregressive coefficient of a given series. $i=1, \ldots, N$ and $t=1, \ldots, T . \quad \alpha_{i}=\rho_{i}-1$ and the lag order $p_{i}$ may differ across regions. I will denote $\operatorname{ADF}(1)$ and $\operatorname{ADF}(0)$ the cases, where $p_{i}=1$ and $p_{i}=0$ for all $i=1, \ldots, N$, respectively.

\footnotetext{
${ }^{5}$ The stationarity tests for the ratios could be complemented by panel tests for cointegration between prices and cash-flows according to Pedroni (1999, 2004). However, the cointegration test often cannot be used because of the different order of integration in prices and rents. In addition, Mikhed and Zemčík (2009a) show that the results of testing for the cointegration relationship between prices and rents in the US are similar to the unit root test results.

${ }^{6}$ Besides the analysis based on prices and rents by Mikhed and Zemčík (2009a), the following studies used available variables on US Metropolitan Statistical Areas and panel data stationarity tests: Malpezzi (1999), Gallin (2006), and Mikhed and Zemčík (2009b). Findings of these studies are consistent with a real estate bubble in the US being inflated in the early 2000s and collapsing around the year 2007.
} 
Peseran (2004) shows that the following statistic is asymptotically normally distributed:

$$
C D=\sqrt{\frac{2 T}{N(N-1)}}\left(\sum_{i=1}^{N-1} \sum_{j=i+1}^{N} \operatorname{Corr}\left(\hat{\epsilon}_{i}, \hat{\epsilon}_{j}\right)\right) \rightarrow N(0,1) .
$$

The $(T \times 1)$ vector of estimated residuals $\hat{\epsilon}_{i}, i=1, \ldots, N$ is estimated using the equation (5). A simple Gauss procedure is written to calculate the test statistic.

Pesaran (2007) proposes a panel data unit root test robust to correlation among regions. It is based on the cross sectionally augmented Dickey-Fuller regression (CADF):

$$
\Delta y_{i t}=\mu_{i}+\omega_{i} t+\alpha_{i} y_{i, t-1}+\sum_{j=1}^{p_{i}} \lambda_{i j} \Delta y_{i, t-j}+v_{i} \bar{y}_{t-1}+\sum_{j=0}^{p_{i}} \varpi_{i j} \Delta \bar{y}_{i, t-j}+\epsilon_{i t},
$$

where $\epsilon_{i t}$ denotes an i.i.d. error term and $\bar{y}_{t}$ is the cross-section mean. Let $\tilde{t}_{i, T_{i}, N}\left(p_{i}\right)$ be the t-statistic for $\alpha_{i}=0$ (a unit root) in the CADF regression. If $p_{i}=p$ for all $i s$ and the panel of data is balanced, $\tilde{t}_{i, T_{i}, N}\left(p_{i}\right)=\tilde{t}_{i}(T, N, p) \cdot \operatorname{CADF}(0)$ and $\operatorname{CADF}(1)$ are defined similarly to $\operatorname{ADF}(0)$ and $\operatorname{ADF}(1)$, respectively. The test proposed in Pesaran (2007) averages t-tests from regional regressions:

$$
\bar{t}^{\dagger}=\frac{1}{N} \sum_{i=1}^{N} \tilde{t}_{i}(N, T, p)
$$

The null hypothesis is defined as

$$
H_{0}: \alpha_{i}=0 \text { for } i=1,2, \ldots, N
$$

and the alternative as

$$
H_{1}: \begin{cases}\alpha_{i}=0 & \text { for } i=1,2, \ldots, N_{1} \\ \alpha_{i}<0 & \text { for } i=N_{1}+1, N_{1}+2, \ldots, N\end{cases}
$$

Rejecting the null hypothesis means that at least one of the series is stationary.

A previous version of this test is described in Im, Pesaran, and Shin (2003). This version does not include the cross-sectional terms in the ADF regression. I will refer to it as the IPS test or the IPS statistic. The cross sectionally augmented version will be denoted as the CIPS test and statistic, respectively. The CIPS statistic is given in (8). The empirical analysis is conducted employing Gauss. Specifically, the IPS test is 
conducted using Nonstationary Panel Time Series Module 1.3 for Gauss (NPT 1.3) from Chihwa Kao. While I have my own versions of the CADF and CIPS tests, I have also used a Gauss procedure from Pesaran (2007). ${ }^{7}$ The number of regions for the available data is $N=335$ for the Czech Republic as a whole and $N=57$ for a selected sub-sample. $T=8$ (2001-2008). Critical values for these dimensions are not available in Pesaran (2007) and are generated by Monte Carlo simulations. The number of Prague's districts is 46 with 20 months of observations. This $N, T$ combination is included in Pesaran (2007).

Finally, equations (2) and (3) suggest that changes in prices and changes in rents are related. This can be tested using the concept of Granger causality in panel data, which was pioneered in Hurlin (2004) and in Hurlin and Venet (2004). Let us consider two stationary variables $y_{i}$ and $x_{j}$. In our case, these would refer to first differences of rents and prices. The following regression model captures a potential relationship between the two variables:

$$
y_{i t}=\mu_{i}+\sum_{l=1}^{L} \varphi_{i}^{(l)} y_{i, t-l}+\sum_{l=1}^{L} \delta_{i}^{(l)} x_{i, j, t-l}+\xi_{i t}
$$

$\xi_{i t}$ follow a normal distribution with a zero mean and a finite variance. which differs across groups. They are i.i.d.. Their mean is zero and the variance is finite. The vectors $\xi_{i}=\left(\xi_{i 1}, \ldots, \xi_{i T}\right)^{\prime}$ are independent for $i \neq j$. The relevant null hypothesis is:

$$
H_{0}: \delta_{i}=0, \forall i=1, \ldots, N
$$

where $\delta_{i}=\left(\delta_{i}^{(1)}, \ldots, \delta_{i}^{(L)}\right)^{\prime} . H_{0}$ captures the notion of Homogeneous Non Causality (HNC), where $x$ is not useful for predicting $y$ after controlling for lags of $y$. The alternative hypothesis is defined as

$$
\begin{aligned}
H_{1}: & \delta_{i}=0, \quad \forall i=1, \ldots, N_{1} \\
& \delta_{i} \neq 0, \quad \forall i=N_{1}+1, \ldots, N
\end{aligned}
$$

where $N_{1} \in[0, N)$ is unknown. Let us define $W_{i t}$ as the Wald statistic from the individual test of $H_{0}$ for $i=1, \ldots, N$ and $W_{N T}^{H N C}=(1 / N) \sum_{i=1}^{N} W_{i T}$. Hurlin (2004) demonstrates

\footnotetext{
${ }^{7}$ Prof. Pesaran was kind enough to email me his code.
} 
that

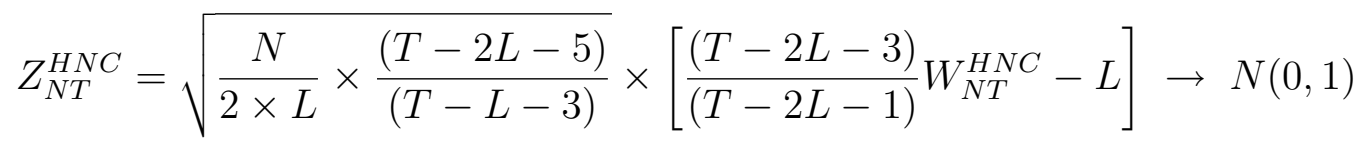

for a fixed $T>5+2 L$ and $N \rightarrow \infty$. The code for the test is written in Stata 9.2. ${ }^{8}$

The restriction $T>5+2 L$ implies that the Hurlin test cannot be used for the annual panel data with the number of effective observations $T=6$ for differences and $T=7$ for levels when $L=1$. Therefore, a different approach needs to be adopted to test for Granger causality. One can estimate the equation (11) using dynamic panel data techniques if $\varphi_{i}=\varphi$ and $\delta_{i}=\delta$ for all $i$. The equation then can be estimated using first differences and the Generalized Method of Moments (GMM) Arellano and Bond (1991) n-step estimator with White correction for heteroskedasticity. Instruments are given by lags 2 and higher of first differences available at time $t$. The t-test with of $\delta=0$ then can be loosely interpreted as a test of Granger causality in panel data.

\section{Data}

Two datasets are used in this paper, both of which contain data on apartment prices and rents. The first is annual and covers the whole Czech Republic, has a somewhat larger cross-sectional dimension and a smaller number of annual observations. The second is monthly and covers Prague districts. It has a larger number of time series observations but for a shorter period due to higher data frequency. The latter dataset enables one to analyze the capital separately, which helps to filter out effects of its higher general price level (i.e. including real estate market information).

\footnotetext{
${ }^{8}$ I would like to thank Vyacheslav Mikhed for supplying the code.
} 


\subsection{The Czech Republic}

We use data from the Institute of Regional Information at Brno (IRI). The IRI's data set contains advertised housing prices and rents for 335 locations from 2001 up to 2008. The regions are listed in the Data Appendix. The housing price and rent expresses price or rent for $1 \mathrm{~m}^{2}$ for the standardized $68 \mathrm{~m}^{2}$ existing (i.e. not newly constructed) apartment.

The housing prices for existing apartments are calculated as follows. First, if there are more then 30 data points in a given location, adjustment is made for size and for the type of all apartments. For example, the price of $1 \mathrm{~m}^{2}$ in an $88 \mathrm{~m}^{2}$ apartment was 0.9453 of the price of $1 \mathrm{~m}^{2}$ in an $68 \mathrm{~m}^{2}$ apartment in 2006. There are two main types: apartments in the socialist style panel buildings and apartments in typically nicer brick buildings.

IRI has also developed a simple algorithm to address a missing data problem, which occurs if there are less then 30 observations in a given location in some period. It divides locations into three categories, reflecting their size and relative importance. 'Fathers' are regional capitals ('krajska mesta' in Czech) and selected district capitals ('okresni mesta' in Czech). There are always 30 observations for cities in this group. Each father has a network of geographically close towns called 'Sons', some of which have 'Grandsons' i.e. close villages and small towns.

Let us define $P_{t}^{F}$ as the price of the standardized $68 \mathrm{~m}^{2}$ apartment for one of the Fathers and $P_{t}^{S}$ the price of the standardized $68 \mathrm{~m}^{2}$ apartment for one of the Sons of this particular Father. Suppose we have an updated price $P_{t+1}^{F}$ for the Father and $n<30$ observations for the Son. Then

$$
\left.P_{t+1}^{S}=\frac{1}{30}\left[\sum_{i=1}^{n} P_{i, t+1}^{S}+(30-n) c_{t} P_{t+1}^{F}\right)\right]
$$

where $P_{i, t+1}^{S}$ are observed prices for the Son. Also, $c_{t+1}=P_{t+1}^{S} / P_{t+1}^{F}$.

The prices are characterized in Figure 1. The average prices were gradually increasing until the Czech Republic joined the European Union in 2004. Then they stagnated in 2005 when a new, more rapid increase started. It continued up to the end of the sample 
in 2008. The mean prices almost tripled over the considered time interval, increasing from 407,725 Kc in 2001 to 1,142,836 Kc in 2008. The standard deviation was relatively small and stable over the whole period. While the minimum prices followed the average ones, their increase was somewhat less dramatic. The maximum prices on the other hand leaded the price increases, being about one year ahead of the mean prices. Clearly, the highest apartment prices are in Prague.

The monthly advertised rents are collected annually for the same sample of 335 locations. The rents are again shown in Figure 1). The pattern is similar to that of the housing prices but with two important differences. First, the mean rents in 2006 were still lower than mean rents in 2004. Second, the maximum Prague rents were declining much faster and longer than prices, from 2003 to 2006, and still stagnating in 2007. Further analysis is needed by constructing price to rent ratios to see if the relationship between prices and rents in the Czech republic was stable in the sample 2001-2008.

Addressing the missing data problem is somewhat more problematic than in the case of the housing prices. The adjustment relies on a relationship between housing prices and rents. Whenever the number of observations was lower than 30 for a given period, the rent was calculated as follows:

$$
R_{t}=P_{t} \frac{k_{t}}{12}+f
$$

where $R_{t}$ is a monthly rent and $P_{t}$ is the housing price, respectively. $f$ is the monthly fixed cost of $1,550 \mathrm{Kc} . k_{t}$ is the annual expected return on investment in housing estimated by IRI to be $7 \%$ from 2003 to 2005 and $6 \%$ from 2006 to 2007 . IRI does not provide information which rate it uses for years 2001, 2002, and 2008. I use integer interest rates with the largest number of observations, for which the difference between rent calculated using equation (15) and the reported rents is less than $1 \mathrm{Kc}$. Interest rates calculated in this way are $k_{2001}=6 \%, k_{2002}=6 \%$, and $k_{2008}=4 \%$, respectively. There were 256 of such cases in 2001 and 202 in 2002. The numbers were at most 32 since then. However, using such rents is clearly not appropriate when one is testing the relationship between 
prices and rents. I therefore exclude ALL reported rents, for which the difference between rent calculated using equation (15) and the reported rents is less than $1 \mathrm{Kc}$ in any year. The resulting sample has 57 cities left, mainly major regional and national centers. The cities in the sample are in the Data Appendix. Only this reduced sample will be used in the subsequent econometric analysis.

Finally, price-rent ratios are calculated using annualized rents for all 335 regions and displayed in Figure 1. The highest ratios in 2008 were in Praha, Olomouc, and Hradec Kralove, all large cities by Czech standards. The population size is above 1 million inhabitants in Praha and slightly above 100,000 in Olomouc and Hradec Kralove. The lowest ratios in 2008 were recorded for small, fairly unknown towns such as Duchcov, Dubi, and Krupka. With the exception of the minimum ratios, the summary statistics were rising at the end of the sample, indicating a potential real estate price bubble. It is subject to formal econometric tests to see if this increase was statistically significant using panel data stationarity tests. Due to the lack of data for rents for small regions, the focus will be mainly on larger cities, effectively eliminating the line for minimum in Figure 1.

\subsection{Prague}

The monthly data for apartment prices and rents per $m^{2}$ from Prague are published in a real estate magazine REALIT and are collected by Vaclav Dolansky. Similarly to the data provided by IRI, these are also advertised prices and rents, with $90 \%$ of information gathered from various servers with offers of apartments for sale and for rent.

The prices have been followed since January 2002 but the data collection was interrupted from April 2002 to June 2002, so the used sample starts in July 2002. There are 46 Prague locations, which are listed in Data Appendix. Since prices for Karlin and Vysocany are not available from July 2002 to November 2002, these districts will be dropped from the stationarity analysis of prices, though not from the analysis of price/rent ratios. 
For illustration, prices for a $68 \mathrm{~m}^{2}$ are calculated for the sake of comparison with the data from IRI, though the dependence of the $m^{2}$ price on the apartment size is not provided by REALIT. Figure 2 shows summary statistics across locations at any given time. The graph reports means with added and subtracted standard deviations to characterize the level and volatility of the prices. The means capture the gradual increases culminating in 2004 when the Czech Republic joined the European Union. The prices stagnated afterwards but picked up again in 2006 and especially in 2007, peaking in the middle of 2008 . There is a noticeable decline starting in the second half of 2008 due to the global financial crises and a recession, as well as due to local factors.

The distribution of prices is positively skewed with just a small number of prime locations with extremely high prices such as Mala Strana, Stare Mesto, and Nove Mesto. These prices followed roughly the same pattern as the average though they are distinctly more volatile. Interestingly, the prices in Mala Strana (the maximum in the figure) actually increased at the end of the sample, defying the overall trend. There have been changes on the low end of the market. In the beginning of the sample, it was Zlicin with the lowest prices. However, this location has been developed and is now no longer considered sub-prime. On the other hand, Haje has stagnated and has become the cheapest location even though the prices were much higher as compared to Zlicin before.

The data on rents have only been collected since July 2007, which leaves us with exactly 20 observations. This is sufficient for stationarity analysis using panel data even though the time span is fairly short. The monthly rents for $68 \mathrm{~m}^{2}$ apartments are in the second part of Figure 2, which depicts the same statistics as for the prices. It also keeps the same time line for a direct comparison with the prices. The average rent started from 15,307 Kc/month in July 2002, peaked at 16,415 Kc/month in May 2007 and was 15,764 $\mathrm{Kc} / \mathrm{month}$ at the end of the sample. The pattern has been fairly close to that of the prices (i.e. in creasing in 2008) but with a faster decline in the second half of 2008 and with smaller differences between the peak and the trough. These findings are supported using 
the price-to-rent ratios at the bottom of Figure 2 (the rents are annualized to calculate the ratios). The ratios had been rising from the start up to November 2008, when a slow decline began. The apartments appear to be overpriced in Prague with the average price/rent ratio still almost 19 and almost 28 in some locations. This provides a starting point for a more rigorous analysis.

\section{Empirical Results}

In this section, I discuss results of the econometric tests over-viewed in Section 3 using data described in Section 4 in the light of theory from Section 2. The tests are conducted both for the Czech Republic and Prague, respectively. First, there is the question of whether the prices and rents are correlated across regions of the Czech Republic and across Prague's districts. Common sense suggests that there should be regional dependence because the Czech Republic is rather small (comparable to smaller states in the United States). Therefore all considered locations are geographically close to each other, and more importantly, they are a part of a small economy with a common fiscal and monetary policy and a legal system. Table 2 confirms this prediction. The Pesaran (2004) CD statistic strongly rejects the null hypothesis of no correlation for the annual national data and for the monthly data from Prague, both at levels and first differences. These test results call for the use of cross sectionally robust stationarity tests of the type suggested in Pesaran (2007).

In the next step, I analyze prices, rents, and price-to-rent ratios using the crosssectionally augmented Dickey-Fuller regression $\mathrm{CADF}(0)$. There are no lagged terms in the regression equation due to a reduced number of time series observations in the annual Czech dataset. The lags can only be included at the cost of dropping the cross-sectional terms. Results presented in Tables 3 and 4 are based only on one of the specifications considered, albeit arguably the one closest to the actual data generating process. Cross- 
sectional dependence in the data requires the cross-sectional terms and a casual look at the graphs in Figure 1 identifies the presence of a trend and intercept in all the series. Robustness to autocorrelation using the lagged terms does not seem to matter in all specifications used but one. This issue will be discussed later when the panel data test results will be analyzed. Note that there are only two levels of significance, one star denotes the standard $10 \%$ level and two stars denote a $6.19 \%$ level of significance. This is because $6.19 \%$ of the estimated t-statistics are equal to -6.42 , the point at which the test values are truncated. Prices are stationary in 10, rents in 5, and price-to-rent ratios in 0 out of 57 regions. This hints the possibility of overvalued apartments in the majority of the tested areas. The highest $P / R$ is reported for Zatec, Prague (Praha in Czech), and Uherske Hradiste. The lowest $P / R$ can be seen in Mlada Boleslav, Nechanice, and Tabor. A formal definition of a bubble corresponds to our four combinations of stationarity of prices and rents in Section 2. One first looks if the price is stationary. A stationary price indicates no bubble in a given region. If the price is not stationary we check the test for rents. Stationary rents and non-stationary prices imply a rational bubble. Finally, in the case where both rents and prices have unit roots, we turn to the price-to-rent ratio. If it is stationary, there is no bubble. Using this algorithm, 44 local bubbles can be identified in the Czech Republic, out of 57 districts. Bubbles are present mainly in bigger cities, such as Prague, Olomouc, or Hradec Kralove. The question is if this will translate into a discrepancy between prices and rents at the national level using the t-statistic averaged across regions.

Similar analysis is conducted for the monthly data regarding 46 districts in Prague see Tables 5 and 6. The series start in January 2003 for the prices and end in July 2007 for the rents, respectively. Hence, the $P / R$ series starts in July 2007 as well. All series end in February 2009. In this case, there are enough observations to use a panel data unit root test with a general specification including the intercept, the time trend, cross-section terms, and lagged terms. The test is then robust to other variables potentially affecting 
the price (the trend takes care of this) and to the presence of both regional dependence and autocorrelation. Apartment prices in 16 of the 46 districts are stationary. There are only 12 stationary rent series. Figure 2 indicates that the price-to-rent ratio has been rising up to the middle of the year 2008 and it has stagnated since then. Formal tests indicate that only 11 of the price-to-rent ratios were stationary in the considered time period. The highest ratios can be observed in Karlin, Holesovice, and Liboc. However, these are not very informative in this case since real estate prices are stationary in Karlin and Liboc. The lowest ratios are in Bubenec, Nusle, and Vysocany. Again, the bubble definition is used to find local discrepancies between prices and rents. Twenty four bubbles are found in 46 Prague districts. Some of these are the usual suspects such as Mala Strana, Nove Mesto, or Vinohrady. Interestingly though, prices in Stare Mesto have been stable over the longer sample.

Finally, the joint panel data tests are conducted with the results reported in Table 7. Several specifications are considered for the overall tests. Regardless of the test used, the price-to-rent ratios are not stationary in Prague, which violates implications of the present value model and indicates overpriced real estate in Prague. For prices and rents, the results are sensitive to the used specification of the regression equation. However, here the most general specification is available. It is robust to regional correlation and to autocorrelation and includes the intercept and the trend. The CADF(1) specification for the CIPS test then implies stationary prices and rents. In spite of the fact that there are no unit roots in either of the series, the present value model is rejected. This is in contrast to the results we saw for individual series. However, the CIPS tests increases its power as compared with the individual tests by taking into account ALL the series at once. The interpretation for the situation in Prague then can be summarized as follows: While there are locations with run-away prices not supported by fundamentals (actually, this is the case for more than half of the locations in the sample), we cannot say that there is a bubble in Prague overall. Such an interpretation is in line with the definition 
of a bubble indicator from Mikhed and Zemčík (2009a). According to this definition, the indicator is 0 for stationary prices. In all other situations, the indicator is set equal to the p-value of the Pesaran (2007) test of stationarity of the price-to-rent ratio. The weak evidence for prices being higher than suggested by the properties of rents is enhanced by the p-value equal to 0.28 for the CIPS test statistic -2.35 reported in Table 7 . This partly reflects the fact, that the Prague sample is shorter and already includes a price decline in the first months of 2009 .

Using the annual data for the Czech Republic as a whole is somewhat complicated due to the fact that there are only 8 years of data, which does not leave one with a sufficient number of degrees of freedom in the $\mathrm{CADF}(\mathrm{p})$ and $\mathrm{ADF}(\mathrm{p})$ type of regressions. To address this issue, all major types of plausible specifications are considered - see Table 7 . The price-to-rent ratio is again non-stationary in all cases. Common regularities appearing in the results for rents and prices are as follows. First, adding lagged terms does not make a difference for any specification where the comparison is possible, which also held true for the data from Prague. For prices, inclusion of a trend seems to matter. Including the trend in the regression equation can be justified visually since the trend in Figure 1 is apparent. From a theoretical perspective, Mikhed and Zemčík (2009b) illustrate that the present value model can be under certain conditions shown to be equivalent to a structural supply and demand model where the real estate price is a function of various supply and demand shifters such as construction costs, personal income, and mortgage rates. In this case, the use of a trend variable is justified since many of the mentioned variables contain trends as well. Therefore, prices are more likely to be non-stationary. With respect to rents, the evidence of a unit root presence is overwhelming. The CIPS test with CADF(0) with the intercept and the trend is the relevant result. However, the present value model is rejected in any case since the price-to-rent ratios are not stationary. I also calculate the bubble indicator according to the definition suggested in Mikhed and Zemčík (2009a). If both prices and rents have a unit root, the indicator is equal to the p-value of the one-sided 
CIPS test statistic. The statistic in our case is -2.59 (see Table 7 ), and the corresponding p-value is 0.20. For comparison, Mikhed and Zemčík (2009a) report values around 0.90 for years 2003-2005 for the US data right before the US bubble started collapsing in 2006 with a bubble indicator of 0.32 . This suggests that while prices are somewhat higher in the Czech Republic as compared to the fundamentals represented by rents, the overpricing is much milder as compared with the United States. Consequently, one can expect the stagnation of real estate prices or perhaps a small decline, but a collapse of the apartment prices is not very likely.

As a final exercise, I focus on predictability of changes in prices using changes in rents, and viceversa. Potential predictability is based on equation (4) and it can be tested using the Hurlin Homogeneous Granger Causality test. The Hurlin test statistic (14) can only be used for $T>5+2 L$, where $L$ is the number of lags in the regression equation (11). If $L=1$, the minimum number of effective observations needed is $T=8$. This precludes the possibility of using the dataset for the Czech Republic, where the effective number of observations is $8-2=6$ for differences and $8-1=7$ for levels. Therefore, the Hurlin tests are conducted for the data from Prague. The tests are calculated using first differences in prices and rents, which are stationary at the $1 \%$ level of significance according the the CIPS test with the specification $\operatorname{CADF}(1) .{ }^{9}$ Table 8 presents the results. Since equation (4) does not give any guide with respect to the direction, in which predictability should work, both possible directions are considered. Changes in prices do not Granger cause changes in rents but the p-value 0.12 is only slightly above the $10 \%$ level of significance. If we compare this with p-value=0.09 for the US data in Mikhed and Zemčík (2009a), we see a similar outcome. The null hypothesis that changes in rents does not Granger cause changes in rents cannot be rejected at the $5 \%$ level of significance. The relevant p-value for the US data in Mikhed and Zemčík (2009a) is 0.11, again a fairly close result.

\footnotetext{
${ }^{9}$ Note that the Hurlin tests are not robust to cross-sectional dependence, present both in the CADF and Hurlin regression equations, where I confirmed this using the Pesaran (2007) test. This may potentially affect the distribution of $Z_{N T}^{H N C}$.
} 
The Hurlin causality tests for the monthly data from Prague are complemented by tests of the coefficient for the lagged explanatory variable in equation (11) being equal to 0 . Table 9 presents the results of these tests, where the null hypothesis of $\delta=0$ is strongly rejected using the t-statistic from the dynamic panel data estimation procedure. This result corresponds to results of the Hurlin tests in the working paper version of Mikhed and Zemčík (2009a), which made use of 273 Metropolitan Statistical Areas in the United States. Overall, the outcome of both Hurlin tests for Prague and coefficient tests for the Czech Republic can be interpreted as a confirmation of the theory represented by equation (4) with the rents being somewhat more useful in predicting prices than vice versa.

\section{Summary}

In this paper, the relationship between Czech real estate prices and rents is evaluated. To the best of my knowledge, this is the first study to analyze a particular housing market in Central and Eastern Europe using panel data stationarity techniques. The analysis is now possible due to newly available panel data unit root tests and due to the availability of panel data in the Czech Republic.

The objective is to find if apartment prices are overvalued as compared with the stream of future cash-flows. The relationship between the two variables is captured using the present-value model. There are two main datasets employed in the paper, annual data from IRI for the whole Czech Republic and monthly data from REALIT for Prague. The IRI data span the period from 2001 to 2008 and the REALIT data the period from July 2007 to February 2009.

The used methodology consists of a set of various panel data techniques, which have been developed only recently. First, I test for potential regional cross-sectional dependence. Second, a panel data unit root test robust to regional cross-dependence is conducted to test for stationarity of the price-to-rent ratios. Finally, the present value model 
predicts that changes in prices should predict changes in rents and vice versa. This prediction is tested using panel data causality tests.

The results are as follows. There is regional inter-dependence for both the IRI and REALIT datasets, which calls for the use of the cross sectionally robust unit root tests. While the results are somewhat sensitive to the used specification, it appears that prices and rents are non-stationary for the whole Czech Republic. The data for the Czech Republic spans the period from 2001 to 2008, which includes the rapidly increasing prices and rents in the early 2000s. The data from Prague cover 20months prior to February 2009, and in this period, both prices and rents are stationary.

The outcome of unit root tests is much more robust for price-to-rent ratios. In both datasets and regardless of the employed specification, the price-to-rent ratios are not stationary. This indicates evidence of overpriced real estate in the Czech Republic. However, the degree of overpricing seems small judged by the p-values of the unit root tests for the price-to-rents ratios. Therefore, one can expect a minor decline of prices in some locations and stagnation in others and not the type of collapse observed in the United States, Spain, or Britain. Finally, the changes in rents predict changes in prices and vice versa, confirming the implications of the present-value model. 


\section{References}

Arellano, M., and S. R. Bond (1991). Some Tests of Specification for Panel Data: Monte Carlo Evidence and an Application to Employment Equations. Review of Economic Studies, 58, 277-297.

Campbell, J. Y. and R. J. Shiller (1987). Cointegration and Tests of Present Value Models. The Journal of Political Economy, 95:5, 1062-1088.

Capozza, D.R. and P.J. Seguin (1996). Expectations, Efficiency, and Euphoria in the Housing Market. Regional Science and Urban Economics 26, 369-386.

Clark, T.E. (1995). Rents and Prices of Housing across Areas of the United States: A Cross-section Examination of the Present Value Model. Regional Science and Urban Economics 25, 237-247.

Egert, B. and D. Mihaljek (2007). Determinants of House Prices in Central and Eastern Europe. Working Paper 236, Bank for International Settlements.

Gallin, J. (2006). The Long-Run Relationship between House Prices and Income: Evidence from Local Housing Markets. Real Estate Economics 34:3, 417-438.

Hamilton, J. D. (1986). On Testing for Self-Fulfilling Speculative Price Bubbles. International Economic Review 27:3, 545-552.

Hamilton, J. D. (1994). Time Series Analysis. Princeton, New Jersey: Princeton University Press.

Hurlin, Ch. (2004). Testing Granger Causality in Hetergoeneous Panel Data Models with Fixed Coefficients. Working Paper 2004-05, Laboratoire d'Economie d'Orléans.

Hurlin, Ch. and B. Venet (2004). Financial Development and Growth: A Re-examination Using a Panel Granger Causality Test. Working Paper 2004-18, Laboratoire d'Economie d'Orléans.

Im, K.S., Pesaran, M.H., and Y. Shin (2003). Testing for Unit Roots in Heterogeneous Panels. Journal of Econometrics 115, 53-74.

Malpezzi, S. (1999). A Simple Error Correction Model of House Prices. Journal of Housing Economics 8, 27-62. 
Mikhed, V. and P. Zemčík (2009a). Testing for Bubbles in Housing Markets: A Panel Data Approach. Journal of Real Estate Finance and Economics 38, 366-386.

Mikhed, V. and P. Zemčík (2009b). Do House Prices Reflect Fundamentals? Aggregate and Panel Data Evidence. Journal of Housing Economics, 18:2, 140-149.

Pedroni, P. (1999). Critical Values for Cointegration Tests in Heterogeneous Panels with Multiple Regressors. Oxford Bulletin of Economics and Statistics 61, 653-70.

Pedroni, P. (2004). Panel Cointegration: Asymptotic and Finite Sample Properties of Pooled Time Series Tests with an Application to the PPP Hypothesis. Econometric Theory 20, 597-625.

Pesaran M.H. (2004). General Diagnostic Tests for Cross Section Dependence in Panels. CESIFO Working Paper 1229.

Pesaran M.H. (2007). A Simple Panel Unit Root Test in the Presence of Cross Section Dependence. Journal of Applied Econometrics, 22:2, 265-312.

Wang, P. (2000). Market Efficiency and Rationality in Property Investment. Journal of Real Estate Finance and Economics, 21:2, 185-201. 


\section{Data Appendix}

\section{National Data - 335 Regions}

As, Bechyn, Bila pod Bezdezem, Benatky nad Jizerou, Benesov, Beroun, Blina, Bilovec, Blansko, Blatna, Blovice, Bohumin, Bor, Boskovice, Brandys nad Labem-Stara Boleslav, Brno, Broumov, Brumov-Bylnice, Bruntal, Breclav, Breznice, Bystrice nad Pernstejnem, Bystrice pod Hostynem, Caslav, Celakovice, Cernosice, Cerveny Kostelec, Ceska Kamenice, Ceska Lipa, Ceska Skalice, Ceska Trebova, Ceske Budejovice, Ceske Velenice, Cesky Brod, Cesky Krumlov, Cesky Tesin, Dacice, Decin, Dobruska, Dobrany, Dobris, Doksy, Domazlice, Dubi, Dubnany, Duchcov, Dvur Kralove nad Labem, Frantiskovy Lazne, Frenstat pod Radhostem, Frydek-Mistek, Frydlant, Frydlant nad Ostravici, Fulnek, Golcuv Jenikov, Hanusovice, Havirov, Havlickuv Brod, Hermanuv Mestec, Hlinsko, Hluboka nad Vltavou, Hlucin, Hodonin, Holesov, Holice, Holysov, Horazdovice, Horni Plana, Horni Slavkov, Horsovsky Tyn, Horice, Horovice, Hostinne, Hostivice, Hradec Kralove, Hredek nad Nisou, Hranice, Hronov, Hrusovany nad Jevisovkou, Humpolec, Hustopece, Cheb, Chlumec nad Cidlinou, Chocen, Chodov, Chomutov, Chotebor, Chrastava, Chrudim, Ivancice, Ivanovice na Hane, Jablonec nad Nisou, Jablonne v Podjestedi, Jablunkov, Jaromer, Jaromeriice nad Rokytnou, Javornik, Jemnice, Jesenik, Jicin, Jihlava, Jilemnice, Jilove u Prahy, Jinddrichuv Hradec, Jirkov, Kadan, Kamenice nad Lipou, Kaplice, Karlovy Vary, Karolinka, Karvina, Kdyne, Kladno Klasterec nad Ohri, Klatovy, Kolin, Konice, Kopidlno, Koprivnice, Kostelec nad Cernymi Lesy, Kostelec nad Orlici, Kraliky, Kralovice, Kralupy nad Vltavou, Kraluv Dvur, Kraslice, Kravare, Krnov, Kromeriz, Krupka, Kunovice, Kurim, Kutna Hora, Kyjov, Kynsperk nad Ohri, Lanskroun, Lazne Belohrad, Lazne Bohdanec, Ledec nad Sazavou, Letohrad, Letovice, Liberec, Libochovice, Lipnik nad Becvou, Lisov, Litomerice, Litomysl, Litovel, Litvinov, Lomnice nad Popelkou, Louny, Lovosice, Luhacovice, Lysa nad Labem, Marianske Lezne, Melnik, Mestec Kralove, Mesto Albrechtice, Mikulov, Milevsko, Mimon, Miroslav, Mlada Boleslav, Mlada Vozice, Mnichovo Hradiste, Mnisek pod Brdy, Mohelnice, Moravska Trebova, Moravske Budejovice, Moravsky Beroun, Moravsky Krumlov, Most, Nachod, Nemest nad Oslavou, Napajedla, Nechanice, Nejdek, Neratovice, Netolice, Nova Bystrice, Nova Paka, Nove Mesto na Morave, Nove Mesto nad Metuji, Nove Mesto pod Smrkem, Nove Straseci, Novy Bor, Novy Bydzov, Novy Jicin, Nymburk, Nyrsko, Nyrany, Odolena Voda, Odry, Olomouc, Opava, Orlova, Ostrava, Ostrov, Otrokovice, Pacov, Pardubice, Pelhrimov, Petrvald, Pisek, Plana, Plzen, Pocatky, Podborany, Podebrady, Pohorelice, Police, nad Metuji, Policka, Polna, Postoloprty, Praha, Prachatice, Prostejov, Protivin, Prelouc, Prerov, Prestice, Pribor, Pribram, Pribyslav, Rakovnik, Rokycany, Rokytnice nad Jizerou, Rokytnice v Orlickych horach, Rosice, Roudnice nad Labem, Rousinov, Roztoky, Rozmital pod Tremsinem, Roznov pod Radhostem, Rumburk, Rychnov nad Kneznou, Rychvald, Rymarov, Ricany, Szava, Sedlcany, Semily, Sezimovo Usti, Skutec, Slany, Slavicin, Slavkov u Brna, Sobeslav, Sobotka, Sokolov, Stankov, Stare Mesto, Stary Plzenec, Stochov, Strakonice, Straznice, Stribro, Studenka, Suchdol nad Luznici, Susice, Svetla nad Sazavou, Svitavy, Senov, Slapanice, Sluknov, Spindleruv Mlyn, Sternberk, Steti, Sumperk, Tabor, Tachov, Tanvald, Telc, Teplice, Tisnov, Touzim, Trhove Sviny, Trutnov, Trebechovice pod Orebem, Trebic, Trebon, Tremosna, Tremosnice, Trest, Trinec, Turnov, Tyn nad Vltavou, Tynec nad Sazavou, Tyniste nad Orlici, Uherske Hradiste, Uhersky Brod, Unhost, Unicov, Upice, Usti nad Labem, Usti nad Orlici, Ustek, Uvaly, Valasske Klobouky, Valassk Mezirici, Vamberk, Varnsdorf, Vejprty, Velka Bites, Velka nad Velickou, Velke Mezirici, Velvary, Veseli nad Moravou, Vimperk, Vitkov, Vizovice, Vlasim, Vodnany, Volary, Votice, Vratimov, Vrbno pod Pradedem, Vrchlabi, Vsetin, Vysoke Myto, Vyskov, Vyssi Brod, Zabreh, Zbiroh, Zlate Hory, Zlin, Znojmo, Zruc nad Sazavou, Zubri, Zacler, Zamberk, Zatec, Zdar nad Sazavou, Zelezna Ruda, Zelezny Brod, Zidlochovice

\section{National Data - Reduced Sample, 57 Regions}

Bilina, Brno, Bruntal, Breclav, Cesky Tesin, Decin, Dubi, Havirov, Hodonin, Hradec Kralove, Cheb, Chomutov, Jablonec nad Nisou, Jihlava, Jirkov, Kadan, Karvina, Kladno, Klasterec nad Ohri, Kolin, 
Koprivnice, Krupka, Liberec, Litomerice, Litvinov, Louny, Mlada Boleslav, Most, Nechanice, Novy Jicin, Olomouc, Opava, Orlova, Pardubice, Pisek, Plzen, Praha, Prostejov, Prerov, Pribram, Sokolov, Spindleruv Mlyn, Sumperk, Tabor, Teplice, Trutnov, Trebic, Uherske Hradiste, Unhost, Usti nad Labem, Valasske Mezirici, Varnsdorf, Vejprty, Vsetin, Zlin, Znojmo, Zatec.

\section{Prague - 46 Districts}

Bohnice, Branik, Brevnov, Bubenec, Cerny Most, Cimice, Dablice, Dejvice, Dolni Chabry, Haje, Hlubocepy, Holesovice, Horni Mecholupy, Horni Pocernice, Hostivar, Chodov, Karlin, Kobylisy, Kosire, Krc, Lhotka, Liben, Liboc, Mala Strana, Modrany, Nove Mesto, Nusle, Pankrac, Prosek, Repy, Smichov,

Sporilov, Stare Mesto, Stodulky, Strasnice, Strizkov, Troja, Veleslavin, Vinohrady, Vokovice, Vrsovice, Vysocany, Zabehlice, Zbraslav, Zlicin, Zizkov. 
Figure 1: Annual Prices, Rents, and Price/Rent Ratios for a Standard $68 \mathrm{~m}^{2}$ Apartment in the Czech Republic, Kc, 335 Regions, 2001-2008

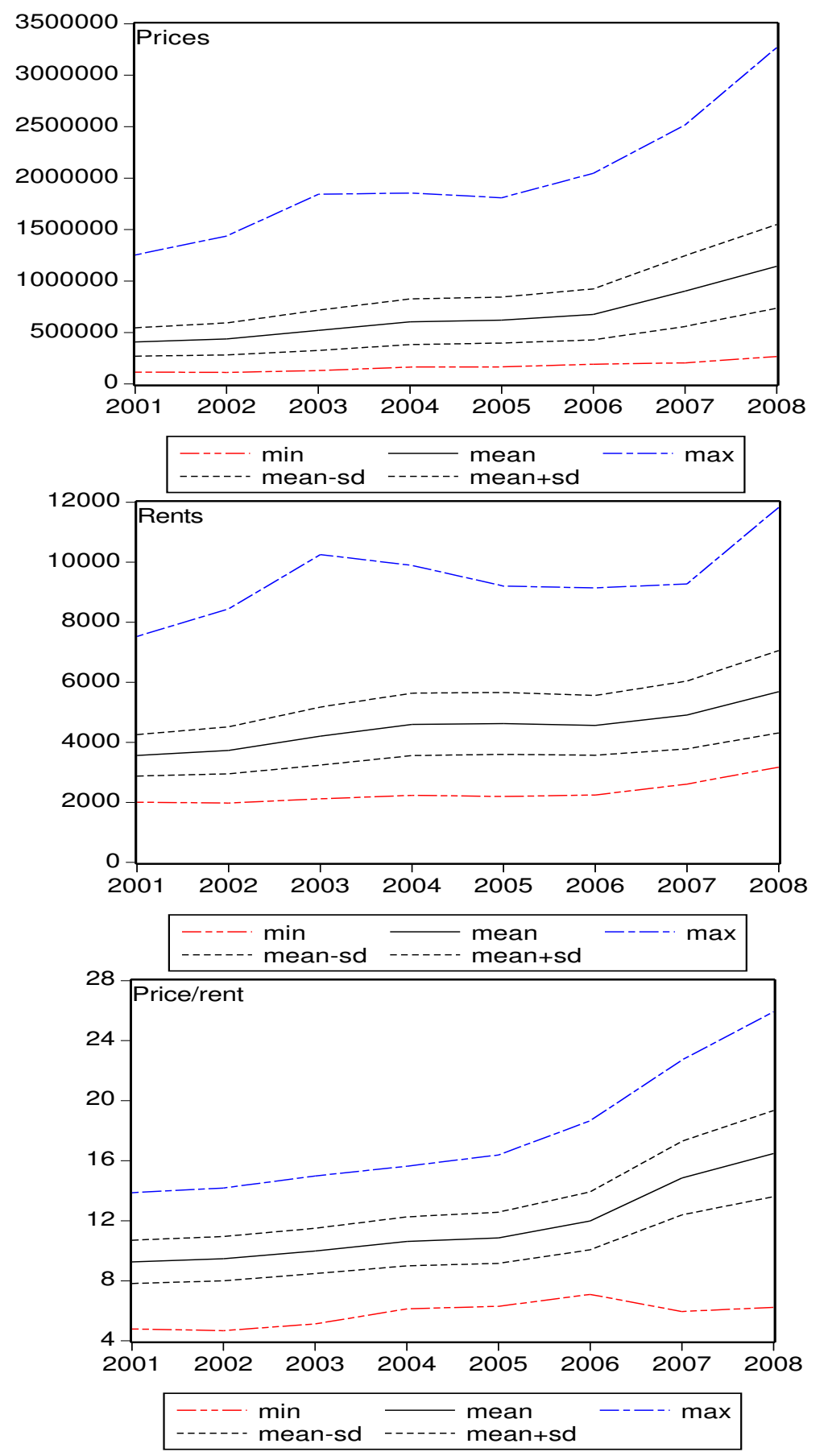


Figure 2: Monthly Prices, Rents, and Price/Rent Ratios for a Standard $68 m^{2}$ Apartment in Prague, Kc

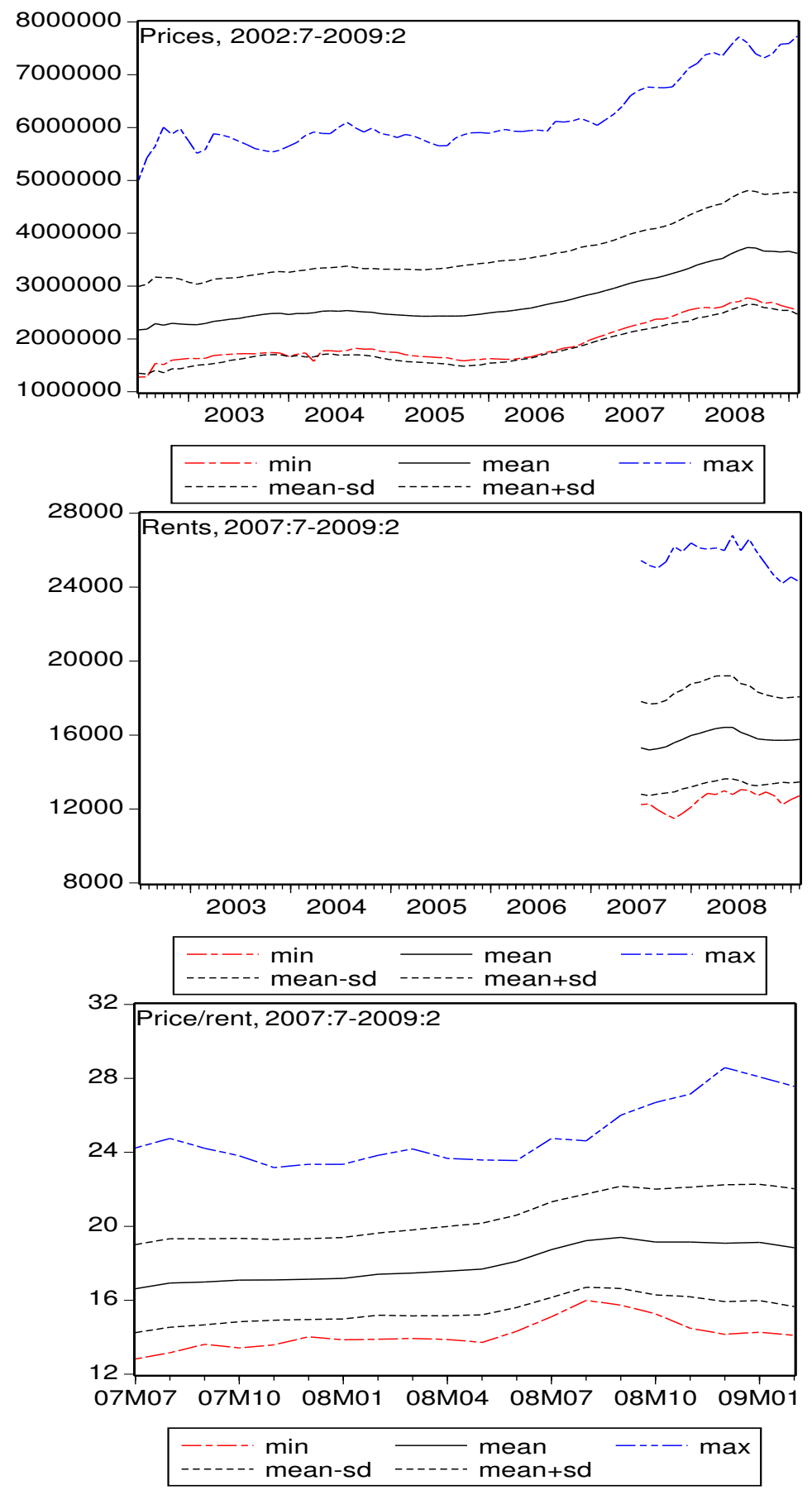


Table 1: Real Estate Price Indexes in Central and Eastern Europe

Notes:

(1) Data sources: Bank of International Settlements except for the Czech Republic, for which the data are from the Institute of Regional Data in Brno (see Data Appendix).

(2) Definitions: Bulgaria - residential property prices of existing apartments in big cities; Czech Republic residential property prices of existing apartments, the whole country; Estonia - residential property prices of existing apartments in Tallinn; Hungary - residential property prices of existing dwellings in Budapest; Latvia - residential property prices of existing apartments, the whole country; Poland - residential property prices, all houses, the whole country; Slovakia - residential property prices of existing dwellings, the whole country.

(3) The data are normalized so that all indexes are 100 in 2003 for all countries.

Year Bulgaria Czech R. Estonia Hungary Latvia Poland Slovakia

\begin{tabular}{|c|c|c|c|c|c|c|c|}
\hline 1997 & & & 42 & & & & \\
\hline 1998 & & & 50 & & & & \\
\hline 1999 & & & 50 & & & & \\
\hline 2000 & 87 & & 51 & & & & \\
\hline 2001 & 89 & 78 & 68 & 88 & & & \\
\hline 2002 & 89 & 84 & 89 & 90 & 98 & & 72 \\
\hline 2003 & 100 & 100 & 100 & 100 & 100 & 100 & 100 \\
\hline 2004 & 148 & 116 & 128 & 109 & 108 & 378 & 115 \\
\hline 2005 & 202 & 119 & 167 & 110 & 137 & 530 & 104 \\
\hline 2006 & 231 & 130 & 254 & 109 & 271 & 429 & 121 \\
\hline 2007 & 298 & 173 & 280 & 111 & & 974 & 150 \\
\hline 2008 & 373 & 220 & 259 & 112 & & & \\
\hline
\end{tabular}


Table 2: Diagnostic Tests for Cross Section Dependence in Panels

Notes:

(1) ADF regression employed in the CD calculation: intercept, trend, and the first lag of the dependent variable.

(2) Under the null of no cross section dependence: $C D \rightarrow N(0,1)$.

(3) $* * *$ - significant at the $1 \%$ level, ** - significant at the $5 \%$ level, ${ }^{*}$ - significant at the $10 \%$ level.

(4) For the national data, the frequency is annual, and the sample period is 2001-2008. For the data from Prague, the frequency is monthly, and the sample period is 2003:JAN

- 2009:FEB for prices and 2007:JUL-2009:FEB for rents, respectively.

\begin{tabular}{lccc}
\hline price-level & price-diff. & rent-level & rent-diff. \\
$C D$ & $C D$ & $C D$ & $C D$ \\
& & & \\
& & \\
& National Data \\
$109.76^{* * *}$ & $79.95^{* * *}$ & $96.61^{* * *}$ & $48.52^{* * *}$ \\
& & \\
$206.65^{* * *}$ & $52.66^{* * *}$ & $34.70^{* * *}$ & $18.25^{* * *}$ \\
& & \\
\hline
\end{tabular}


Table 3: Cross sectionally Augmented Dickey-Fuller Tests - Czech Republic 1/2

Notes:

(1) The cross sectionally augmented Dickey-Fuller tests with an intercept, a trend, the difference of the cross section mean and the first lag of the cross-section mean. No lags of the differenced dependent variable are included. The test is denoted CADF $(0)$.

(3)The critical values are generated using the procedure from Pesaran (2007). ** - significant at the $6.19 \%$ level (i.e. $6.19 \%$ of 10,000 generated t-statistics has the truncated value of $-6.42, *$ - significant at the $10 \%$ level.

(4) Annual data, the sample period is 2001-2008, and there are 57 regions.

\begin{tabular}{|c|c|c|c|c|c|c|c|}
\hline & Prices & & Rents & & $\mathrm{P} / \mathrm{R}$ & & Rank \\
\hline Bilina & -6.42 & $* *$ & 1.70 & & -2.91 & & 36 \\
\hline Breclav & -0.25 & & -2.67 & & -2.89 & & 35 \\
\hline Brno & -4.07 & & 0.23 & & -2.06 & & 21 \\
\hline Bruntal & 0.88 & & -1.00 & & -2.60 & & 32 \\
\hline Cesky Tesin & -0.84 & & -1.24 & & 0.44 & & 4 \\
\hline Cheb & -1.47 & & -2.02 & & -1.82 & & 17 \\
\hline Chomutov & -3.49 & & 0.06 & & -2.94 & & 38 \\
\hline Decin & -5.73 & $*$ & -3.53 & & -3.88 & & 45 \\
\hline Dubi & -1.58 & & 1.70 & & -3.43 & & 41 \\
\hline Havirov & 0.16 & & -0.51 & & -0.76 & & 5 \\
\hline Hodonin & -1.02 & & -3.88 & & -1.16 & & 12 \\
\hline Hradec Kralove & -3.86 & & -3.16 & & -1.02 & & 10 \\
\hline Jablonec nad Nisou & -6.42 & $* *$ & -0.80 & & -3.65 & & 42 \\
\hline Jihlava & 1.70 & & 0.78 & & -2.27 & & 28 \\
\hline Jirkov & -6.42 & $*$ & 0.41 & & -2.11 & & 23 \\
\hline Kadan & -0.31 & & 1.70 & & -5.66 & $*$ & 54 \\
\hline Karvina & 0.54 & & 0.47 & & -0.78 & & 6 \\
\hline Kladno & -2.72 & & -0.39 & & -2.92 & & 37 \\
\hline Klasterec nad Ohri & -1.80 & & 1.70 & & -2.16 & & 25 \\
\hline Kolin & -3.00 & & -6.42 & $* *$ & -4.59 & & 50 \\
\hline Koprivnice & -0.57 & & -6.42 & $* *$ & -4.11 & & 46 \\
\hline Krupka & -2.30 & & -1.31 & & -3.79 & & 44 \\
\hline Liberec & -2.15 & & 0.20 & & -2.65 & & 33 \\
\hline Litomerice & -2.41 & & -6.22 & $*$ & -2.42 & & 30 \\
\hline Litvinov & -0.95 & & 1.70 & & -0.88 & & 9 \\
\hline Louny & -0.50 & & -1.82 & & -0.83 & & 8 \\
\hline Mlada Boleslav & -1.33 & & -2.74 & & -6.42 & $* *$ & 57 \\
\hline Most & -1.43 & & 1.70 & & -2.09 & & 22 \\
\hline Nechanice & -6.42 & $* *$ & 1.70 & & -6.42 & $* *$ & 56 \\
\hline
\end{tabular}


Table 4: Cross sectionally Augmented Dickey-Fuller Tests - Czech Republic 2/2

Notes:

(1) The cross sectionally augmented Dickey-Fuller tests with an intercept, a trend, and the difference of the cross section mean, and the first lag of the cross-section mean. No lags of the differenced dependent variable are included. The test is denoted $\operatorname{CADF}(0)$.

(3) The critical values are generated using the procedure from Pesaran (2007). ** - significant at the $6.19 \%$ level (i.e. $6.19 \%$ of 10,000 generated t-statistics has the truncated value of $-6.42, *$ - significant at the $10 \%$ level.

(4) Annual data, the sample period is 2001-2008, and there are 57 regions.

\begin{tabular}{|c|c|c|c|c|c|c|c|}
\hline & Prices & & Rents & & $\mathrm{P} / \mathrm{R}$ & & Rank \\
\hline Novy Jicin & -2.45 & & -2.69 & & -0.82 & & 7 \\
\hline Olomouc & -4.27 & & -1.09 & & -4.58 & & 49 \\
\hline Opava & -2.23 & & -2.76 & & -3.31 & & 39 \\
\hline Orlova & 1.70 & & -1.33 & & -4.49 & & 48 \\
\hline Pardubice & -0.41 & & -0.87 & & -2.66 & & 34 \\
\hline Pisek & -2.43 & & -5.75 & $*$ & -1.42 & & 14 \\
\hline Plzen & -1.09 & & -0.25 & & -4.92 & & 53 \\
\hline Praha & -1.94 & & -1.25 & & 1.54 & & 2 \\
\hline Prerov & -2.86 & & -3.45 & & -3.71 & & 43 \\
\hline Pribram & -5.43 & $*$ & -2.00 & & -4.31 & & 47 \\
\hline Prostejov & -6.42 & $* *$ & 0.11 & & -2.17 & & 26 \\
\hline Sokolov & -2.03 & & 0.52 & & -2.16 & & 24 \\
\hline Spindleruv Mlyn & -0.93 & & -1.72 & & -2.00 & & 18 \\
\hline Sumperk & -2.14 & & -1.80 & & -2.22 & & 27 \\
\hline Tabor & -3.36 & & 1.48 & & -6.42 & $* *$ & 55 \\
\hline Teplice & -6.15 & $*$ & -0.70 & & -1.82 & & 16 \\
\hline Trebic & -4.13 & & -1.74 & & -2.06 & & 20 \\
\hline Trutnov & -6.42 & $* *$ & -2.84 & & -2.38 & & 29 \\
\hline Uherske Hradiste & -1.81 & & -5.14 & $*$ & 0.79 & & 3 \\
\hline Unhost & -3.14 & & -0.62 & & -4.63 & & 51 \\
\hline Usti nad Labem & -6.00 & $*$ & -0.62 & & -3.33 & & 40 \\
\hline Valasske Mezirici & -3.58 & & -1.41 & & -2.06 & & 19 \\
\hline Varnsdorf & -1.96 & & -0.99 & & -4.78 & & 52 \\
\hline Vejprty & -1.44 & & 0.44 & & -2.60 & & 31 \\
\hline Vsetin & -3.09 & & -1.74 & & -1.70 & & 15 \\
\hline Zatec & -0.56 & & 0.65 & & 1.70 & & 1 \\
\hline Zlin & -2.97 & & -1.65 & & -1.21 & & 13 \\
\hline Znojmo & -1.19 & & -0.27 & & -1.08 & & 11 \\
\hline
\end{tabular}


Table 5: Cross sectionally Augmented Dickey-Fuller Tests - Prague 1/2

Notes:

(1) The cross sectionally augmented Dickey-Fuller tests with an intercept, a trend, and the difference of the cross section mean and the first lag of the cross-section mean. One lag of the differenced dependent variable is included. The test is denoted CADF(1).

(3)The critical values are from Pesaran (2007). *** - significant at the $1 \%$ level, ** significant at the $5 \%$ level, ${ }^{*}$ - significant at the $10 \%$ level.

(4) The frequency is monthly, and the sample period is 2003:JAN - 2009:FEB for prices and 2007:JUL-2009:FEB for rents, respectively.

\begin{tabular}{|c|c|c|c|c|c|c|c|}
\hline & Prices & & Rents & & $\mathrm{P} / \mathrm{R}$ & & Rank \\
\hline Bohnice & -2.26 & & -2.43 & & -1.85 & & 23 \\
\hline Branik & -4.38 & $* *$ & -3.16 & & -1.66 & & 20 \\
\hline Brevnov & -3.85 & $* *$ & -6.42 & $* * *$ & -1.29 & & 11 \\
\hline Bubenec & -2.44 & & -2.18 & & -6.42 & $* * *$ & 46 \\
\hline Cerny Most & -5.67 & $* * *$ & -3.26 & & -1.06 & & 9 \\
\hline Chodov & -2.2 & & -2.85 & & 0.11 & & 4 \\
\hline Cimice & -4.89 & $* * *$ & -3.49 & & -3.66 & $*$ & 36 \\
\hline Dablice & -2.58 & & -1.73 & & -1.45 & & 17 \\
\hline Dejvice & -1.93 & & -2.48 & & -2.96 & & 32 \\
\hline Dolni Chabry & -0.16 & & -4.83 & $* *$ & -2.7 & & 29 \\
\hline Haje & -0.11 & & -4.38 & $* *$ & -1.05 & & 7 \\
\hline Hlubocepy & -2.73 & & -3.06 & & -2.52 & & 25 \\
\hline Holesovice & -1.38 & & -2.1 & & 0.49 & & 2 \\
\hline Horni Mecholupy & -2 & & -1.85 & & -1.54 & & 18 \\
\hline Horn Pocernice & -2.69 & & -3.55 & & -4.01 & $*$ & 39 \\
\hline Hostivar & -4.39 & $* *$ & -5.02 & $* *$ & -5.32 & $* *$ & 43 \\
\hline Karlin & -4.88 & $* * *$ & -1.51 & & 1.7 & & 1 \\
\hline Kobylisy & -3.19 & & -1.87 & & -2.55 & & 27 \\
\hline Kosire & -2.89 & & -3.43 & & -1.3 & & 12 \\
\hline Krc & -4.42 & $* * *$ & -4 & $*$ & -1.82 & & 22 \\
\hline Lhotka & -4.24 & $* *$ & -2.99 & & -4.39 & $* *$ & 40 \\
\hline Liben & -1.69 & & -2.15 & & -1.55 & & 19 \\
\hline Liboc & -3.71 & $*$ & -1.09 & & 0.12 & & 3 \\
\hline
\end{tabular}


Table 6: Cross sectionally Augmented Dickey-Fuller Tests - Prague 2/2

Notes:

(1) The cross sectionally augmented Dickey-Fuller tests with an intercept, a trend, and the difference of the cross section mean and the first lag of the cross-section mean. One lag of the differenced dependent variable is included. The test is denoted CADF(1).

(3)The critical values are from Pesaran (2007). *** - significant at the $1 \%$ level, ** significant at the $5 \%$ level, ${ }^{*}$ - significant at the $10 \%$ level.

(4) The frequency is monthly, and the sample period is 2003:JAN - 2009:FEB for prices and 2007:JUL-2009:FEB for rents, respectively.

\begin{tabular}{|c|c|c|c|c|c|c|c|}
\hline & Prices & & Rents & & $\mathrm{P} / \mathrm{R}$ & & Rank \\
\hline Mala Strana & -2.41 & & -2.06 & & -2.69 & & 28 \\
\hline Modrany & -3.03 & & -2.77 & & -4.73 & $* *$ & 41 \\
\hline Nove Mesto & -2.52 & & -2.59 & & -2.97 & & 33 \\
\hline Nusle & -5.45 & $* * *$ & -4.49 & $* *$ & -5.7 & $* * *$ & 45 \\
\hline Pankrac & -3.83 & $* *$ & -1.62 & & -1.66 & & 21 \\
\hline Prosek & -0.54 & & -3.06 & & -1 & & 6 \\
\hline Repy & -2.8 & & -3 & & -2.13 & & 24 \\
\hline Smichov & -0.41 & & -2.38 & & -1.05 & & 8 \\
\hline Sporilov & -2.32 & & -2.38 & & -1.37 & & 13 \\
\hline Stare Mesto & -3.53 & $*$ & -2.58 & & -1.37 & & 14 \\
\hline Stodulky & -3.46 & $*$ & -3.91 & $*$ & -3.73 & $*$ & 37 \\
\hline Strasnice & -2.41 & & -2.77 & & -4.75 & $* *$ & 42 \\
\hline Strizkov & -2.96 & & -4.05 & $*$ & -2.9 & & 31 \\
\hline Troja & -1.76 & & -3.66 & $*$ & -1.06 & & 10 \\
\hline Veleslavin & -2.4 & & -2.25 & & -2.99 & & 34 \\
\hline Vinohrady & -2.82 & & -3.33 & & -1.42 & & 15 \\
\hline Vokovice & -2.4 & & -3.83 & $*$ & -3.76 & $*$ & 38 \\
\hline Vrsovice & -5.31 & $* * *$ & -2.74 & & -0.39 & & 5 \\
\hline Vysocany & -0.91 & & -3.56 & & -5.54 & $* * *$ & 44 \\
\hline Zabehlice & -3.9 & $* *$ & -3.12 & & -1.43 & & 16 \\
\hline Zbraslav & -4.69 & $* * *$ & -4.97 & $* *$ & -3.53 & & 35 \\
\hline Zizkov & -2.68 & & -4.21 & $* *$ & -2.52 & & 26 \\
\hline Zlicin & -2.28 & & -2.74 & & -2.82 & & 30 \\
\hline
\end{tabular}


Table 7: Panel Data Unit Root Tests

Notes:

(1) The IPS test is based on the Augmented Dickey-Fuller regressions with the first lag of the dependent variable $(\operatorname{ADF}(1))$. The specification may include an intercept and a trend. The specification for the CIPS test uses the cross sectionally augmented version of these regressions. CADF (0) does not include any lags of the differenced dependent variable while $\mathrm{CADF}(1)$ includes the first lag. $\mathrm{CADF}(0)$ also includes the difference of the crosssection mean and the first lag of the cross-section mean. The CADF(1) specification adds the first lag of the difference of the cross section mean. For both tests, the null hypothesis is that of a unit root and the alternative hypothesis is that at least one of the series is stationary.

(2)IPS has an asymptotic standardized normal distribution.Critical values for the CIPS statistic are from Pesaran (2007), Table II. For T=6 (i.e. 8 data points), the critical values are generated using the procedure from Pesaran (2007).

(3) $* * *$ - significant at the $1 \%$ level, ${ }^{* *}$ - significant at the $5 \%$ level, ${ }^{*}$ - significant at the $10 \%$ level.

(4) For the national data, the frequency is annual, the sample period is 2001-2008, and there are 57 regions. For the data from Prague, the frequency is monthly, and the sample period is 2003:JAN - 2009:FEB for prices and 2007:JUL-2009:FEB for rents, respectively. There are 46 districts.

\begin{tabular}{|c|c|c|c|c|c|c|}
\hline Test & Specification & Prices & & Rents & & $\mathrm{P} / \mathrm{R}$ \\
\hline \multicolumn{7}{|c|}{ Prague } \\
\hline CIPS & int., trend, $\mathrm{CADF}(0)$ & -2.74 & $* *$ & -2.11 & & -2.00 \\
\hline CIPS & int., trend, $\mathrm{CADF}(1)$ & -2.90 & $* * *$ & -3.09 & $* * *$ & -2.35 \\
\hline IPS & int., trend, $\operatorname{ADF}(1)$ & 1.00 & & -2.66 & $* * *$ & -1.13 \\
\hline \multicolumn{7}{|c|}{ Czech Republic } \\
\hline CIPS & no int., no trend, $\mathrm{CADF}(0)$ & -1.44 & $*$ & -0.92 & & -1.07 \\
\hline CIPS & no int., no trend, $\mathrm{CADF}(1)$ & -1.56 & $* *$ & -0.83 & & -1.12 \\
\hline CIPS & int., no trend, $\mathrm{CADF}(0)$ & -2.61 & $* *$ & -1.42 & & -1.00 \\
\hline CIPS & int., no trend, CADF (1) & -3.03 & $* * *$ & -2.03 & & -1.56 \\
\hline CIPS & int., trend, $\mathrm{CADF}(0)$ & -2.51 & & -1.22 & & -2.59 \\
\hline IPS & int., no trend, $\mathrm{ADF}(1)$ & 16.28 & & 7.12 & & 14.41 \\
\hline IPS & int., trend, $\mathrm{ADF}(1)$ & 1.84 & & -14.16 & $* * *$ & 7.56 \\
\hline
\end{tabular}


Table 8: Hurlin Tests for Homogeneous Non-Causality in Panel Data

Notes:

(1) Under the null of no Homogeneous Granger Causality, $Z_{N T}^{H N C} \rightarrow N(0,1)$.

(2) P-values for two-sided tests are reported.

(3) Only the data from Prague are used, the frequency is monthly, and the sample period is 2007:JUL-2009:FEB, respectively. There are 46 districts.

\begin{tabular}{|c|c|c|}
\hline$H_{0}$ & $Z_{N T}^{H N C}$ & $\mathrm{P}$-value \\
\hline Prague & & \\
\hline price-diff. does not Granger cause rent-diff. & 1.55 & 0.12 \\
\hline rent-diff. does not Granger cause price-diff. & 2.15 & 0.03 \\
\hline
\end{tabular}


Table 9: Tests for Causality in Panel Data

Notes:

(1) Estimated equation: $\Delta y_{i t}=\varphi \Delta y_{i, t-l}+\delta \Delta x_{i, j, t-l}+\Delta \xi_{i t}$.

(2)The data for CR, 2001-2008, 57 regions.

(3) GMM Arellano-Bond n-step estimator with White correction for heteroskedasticity.

(4)Instruments: lags 2 and higher of first differences in prices and rents available at time $t$.

Coefficient Estimate S.e. T-stat. Prob.

\begin{tabular}{lrrrr}
\hline \multicolumn{6}{c}{ Price as the dep. var. } \\
$\varphi$ & 1.8528 & 0.0313 & 59.11 & 0 \\
$\delta$ & -19.9272 & 0.8458 & -23.56 & 0 \\
\multicolumn{5}{c}{} \\
$\varphi$ & Rent as the dep. var. \\
$\delta$ & 0.1305 & 0.0304 & 4.30 & 0 \\
& 0.0059 & 0.0006 & 10.43 & 0 \\
\hline
\end{tabular}


Individual researchers, as well as the on-line and printed versions of the CERGE-EI Working Papers (including their dissemination) were supported from the following institutional grants:

- Economic Aspects of EU and EMU Entry [Ekonomické aspekty vstupu do Evropské unie a Evropské měnové unie], No. AVOZ70850503, (2005-2010);

- Economic Impact of European Integration on the Czech Republic [Ekonomické dopady evropské integrace na ČR], No. MSM0021620846, (2005-2011);

Specific research support and/or other grants the researchers/publications benefited from are acknowledged at the beginning of the Paper.

(c) Petr Zemčík, 2009.

All rights reserved. No part of this publication may be reproduced, stored in a retrieval system or transmitted in any form or by any means, electronic, mechanical or photocopying, recording, or otherwise without the prior permission of the publisher.

Published by

Charles University in Prague, Center for Economic Research and Graduate Education (CERGE) and

Economics Institute ASCR, v. v. i. (EI)

CERGE-El, Politických vězňŭ 7, 11121 Prague 1, tel.: +420 224005 153, Czech Republic.

Printed by CERGE-EI, Prague

Subscription: CERGE-EI homepage: http://www.cerge-ei.cz

Editors: Directors of CERGE and EI

Managing editors: Deputy Directors for Research of CERGE and EI

ISSN 1211-3298

ISBN 978-80-7343-191-4 (Univerzita Karlova. Centrum pro ekonomický výzkum

a doktorské studium)

ISBN 978-80-7344-180-7 (Národohospodářský ústav AV ČR, v. v. i.) 
CERGE-EI

P.O.BOX 882

Politických vězňů 7

11121 Praha 1

Czech Republic http://www.cerge-ei.cz 